\title{
The Humanitarian and Social Agenda of the UN Security Council ${ }^{1}$
}

\author{
M. Lebedeva, M. Ustinova
}

Marina Lebedeva, PhD (Psychology), D. Sc. (Political Science), Professor, the Head of World Politics Department of Moscow State Institute of International Relations (University) of the Ministry of Foreign Affairs Russian Federation (MGIMO University); 76 Prospect Vernadskogo, Moscow, 119454, Russian Federation; E-mail: mmlebedeva@gmail.com

Marina Ustinova, Senior Inspector, Division of Relations with International Development Banks, Department of International Financial Relations, Ministry of Finance of the Russian Federation; 9 Ilyinka Ulitsa, Moscow, 109097, Russian Federation; E-mail: mari.306@mail.ru

\begin{abstract}
By the end of XX - the beginning of XXI century the importance of humanitarian and social issues in the world has sharply increased. Humanitarian and social means began to be intensively included in military and economic actions and play a significant independent role. As a result, there was an increase in the importance of "soft security" aspects, and an expan- sion of this field.

This has affected the UN Security Council, which began to pay more attention to humanitarian and social issues, which was demonstrated with the statistical method.

The range of humanitarian issues discussed by the Security Council and the list of actors sponsoring resolutions on humanitarian issues has expanded. In the late 1990s - early 2000s the Council begins to consider large amount of humanitarian issues: security issues of individuals in armed conflicts (civilians, children, women, UN and humanitarian personnel); civilian aspects of conflict management and peacebuilding; and separate issues of "soft security" (humanitarian assistance and such "soft threats" to security as HIV/AIDS epidemics, food crises and climate change). In addition, the Council also addresses human rights violations.

The promotion of humanitarian issues in the Council on separate occasions was facilitated by high-ranking officials who put a premium on humanitarian issues; various UN bodies and organizations, mainly with humanitarian mandates; some non-permanent members of the Security Council who wanted to leave their mark in the Council's history; various NGOs. In turn, some countries opposed the adoption of measures that they consider to be within the internal competence of their states.

At the same time, the expansion of humanitarian and social problems in the world poses a dilemma for the Security Council: whether to include the entire range of these issues on the agenda, or it is beyond the scope of the Council's man-date. There is no definite answer here. On the one hand, the world is moving along the path of strengthening humanitarian problems and its ever-greater involvement in security issues. On the other hand, an expanded interpretation of security can impede the work of the Council.
\end{abstract}

Key words: world politics; humanitarian agenda; social agenda; soft security; UN; UN Security Council

For citation: Lebedeva M., Ustinova M. (2020) Humanitarian and Social Agenda of the UN Security Council. International Organisations Research Journal, vol. 15, no 1, pp. 135-154 (in English). DOI: 10.17323/19967845-2020-01-06.

${ }^{1}$ The editorial board received the article in September 2019. 


\section{Introduction}

Studies on social and humanitarian issues are attracting increasing attention from both politicians and scientists. As a rule, researchers and practitioners divide social and humanitarian issues into two different areas. Social issues to a greater extent are the focus of economists and sociologists, while humanitarian issues capture the attention of specialists in the field of international relations and world politics. In international studies, it is common to single out specifically humanitarian issues. At the same time, when analyzing humanitarian issues, it is important to indicate the social aspects which in one way or another accompany the humanitarian component of international relations and world politics. Thus, during the provision of humanitarian assistance in emergency situations or conflicts, it is common to identify the least-protected social groups that need humanitarian assistance in the first place. In general, grappling with social problems such as migration, drug addiction, and others involves finding solutions to humanitarian issues. In addition, social ties are determined by many variables, including humanitarian issues related to culture and traditions. Therefore, the success of various humanitarian projects depends on the social relations in a society. Since the humanitarian sphere is closely connected with the social, it makes sense to combine them in this study.

One of the first questions that arises when analyzing social and humanitarian issues is the role of such issues in world politics and the extent to which this is reflected in United Nations (UN) Security Council resolutions. The hypothesis of this study is that as the importance of social and humanitarian issues in world politics increases, this should be reflected in the discussion of relevant issues and the adoption of resolutions on them by the UN Security Council.

It should be noted that many domestic and foreign studies are devoted to various activities of the UN Security Council. However, the social and humanitarian aspects of the work of the Security Council (as compared to the work of the UN Development Programme) have been understudied and often are addressed only in the context of other issues. Therefore, the most important task is to analyze the humanitarian and social issues in the work of the UN Security Council

\section{The Growing Role of Social and Humanitarian Problems in World Politics}

Social and humanitarian issues were on the periphery of politics for a long time, as illustrated by the fact that, in international agreements, the mention of social and humanitarian issues was usually secondary to military, political and economic ones. To a large extent, this structure is preserved today, with the exception of cases where the agreements relate exclusively to the social or humanitarian spheres.

However, social and humanitarian issues are increasingly being included as military and political means of influence. This gives rise to the phenomena of hybrid wars and information wars, which have received wide attention and analysis in the scientific literature [Tsygankov, 2015, pp. 7-32]. Information warfare has become a constant satellite of conflict. The development of the Internet and social networks has allowed information to have an effective impact on the behaviour of parties to a conflict. The rapid dissemination of information on social networks has engendered the large-scale phenomenon of fake news. In hybrid wars, along with military and economic means, social means of influence are actively used, for example, by creating groups of local residents promoting the interests of a foreign state. Conflicts are always accompanied by social and humanitarian problems. The impact of these problems, including the provision of assistance both at the time of conflict and during the post-conflict settlement, has 
a powerful effect on the conflict itself and on the international image of the donor [Stepanova, 2007]. Often it is this image impact, which implies the growth of international influence, that is most significant for the one who provides assistance. In the future, this image can be turned into a kind of economic and political means of imposing economic, ideological and political norms and values on the recipient state, as representatives of neo-Marxism often suggest, starting from A. Gramsci's idea of cultural hegemony [Gramsci, 1957a; 1957b; 1959].

Within the framework of security issues, terrorism and the fight against terrorism occupy a special place in the modern world. International terrorist organizations such as Al-Qaida and the Islamic State (ISIS) actively use social and humanitarian resources to mobilize their supporters, promising justice, social protection and assistance to the poor. Obviously, countering terrorism is impossible without addressing social and humanitarian issues.

In addition to states, international non-governmental organizations (NGOs) are becoming increasingly involved in conflicts. In addition to organizations like the Red Cross which have traditionally provided humanitarian assistance to the victims of conflict, new organizations have appeared, although their activities in the humanitarian and social fields are not always unambiguous. For example, the White Helmets, an NGO operating in Syria and controlled by groups opposing the Syrian government, positions itself as an organization providing medical care to the population. At the same time, according to media reports, it was involved in the creation of fake videos accusing the Syrian government of using poisonous substances [Komsomolskaya Pravda, 2018].

In general, it must be borne in mind that social and humanitarian issues in conflicts can be used in two ways - both within the framework of assistance and cooperation, and to counteract the enemy in conflict relations. The boundaries between these spheres are extremely mobile, and at the same time one entity can provide both assistance to the population in conflict zones and informational opposition to the enemy, including using fake news. This applies not only to the military and political spheres, but also to other areas.

Finally, in the field of security ideas about "soft security" - which implies protection from non-military threats including informational, environmental and social (that is, directly related to human life) [Buzan, 1983; Buzan, Waever, De Wilde, 1998; Galtung, 1969] - have been developing since the end of the 20th century. The concept of human security discussed by the UN Development Programme (UNDP) [1994] precisely implies the protection of the individual and their interests and values.

As for the international economic sphere, in the 21st century, the social and humanitarian activities of businesses have reached beyond the company (social support for their employees) and country (sponsoring important social projects) and are actively operating on the international stage. One of the most striking examples is the Global Compact, created by an initiative of the UN, which aims at increasing the social responsibility of business on a global scale [UN, 2000b]. Businesses that join the Global Compact strengthen their image position on the international stage, which affects, among other things, their profit. For the same reasons, large corporations enter into agreements with international sports organizations and sponsor foreign sports clubs. For example, Gazprom, Ford, Sony, UniCredit, Heineken and MasterCard cooperate with the Union of European Football Associations (UEFA), which gives them the opportunity to place their ads at all matches of the Champions League. Gazprom also cooperates with foreign football clubs, in particular, Schalke and Chelsea [Bombardir.ru, 2018], which strengthens the company's image on the European continent.

In general, business is increasingly paying attention to global issues, including environmental ones, by financing related projects. The activities of BP, which develops and implements approaches aimed at sustainable development [BP, 2005], are a striking example. In addition, the use of various forms of lobbying at the international level can be seen as attracting a social 
resource for business, since lobbying affects certain social groups. This activity is most evident in the European Union (EU) [Rudenkova, 2015].

World politics clearly demonstrates a turn toward the social and humanitarian spheres. There are many examples. First, there has been an expansion of spheres that were not previously considered to be matters of international politics but which are related to people and the development of human capital. Thus, higher education today has become one of the important areas of the application of soft power, but it is not limited to this - along with new technologies it is acquiring a politically significant function. It is no coincidence that the Europeans, having discovered a lag in technological development compared to the U.S. and a number of other countries, have initiated the Bologna Process [Lebedeva, 2006].

The issue of global health is a new and rapidly developing area in international research. It is related to many other issues in the framework of international relations - environment, climate change, the spread of diseases, and feminist studies [Davies et al., 2014]. Tourism and various spheres of culture are also becoming new areas for international research directly related to the individual.

Another indicator of the growing interest in social and humanitarian issues is the ongoing attention to the concept of "soft power" by J. Nye [1990]. Critiques of the concept and research on various aspects of "soft power" both demonstrate the importance of social and humanitarian impact.

Finally, one should pay attention to S. Strange's concept of "structural power" - the ability to create norms and rules which govern the actions of other actors in world politics [1989]. Structural power also constitutes a social and humanitarian resource.

Thus, there is a sharp increase in the importance of social and humanitarian issues and, accordingly, the demand for relevant resources in world politics [Lebedeva, 2014]. Moreover, these issues and resources go beyond the traditional understanding of humanitarian problems in international relations and include many aspects that are otherwise connected with individuals. The reasons for this lie in the fact that humanity has reached a point of development at which attention is focused on the personality and its development. This is facilitated by technologies that ensure communication, information, and the development of creativity, as well as the transparency of national borders and the entry of the masses into the international arena.

At the same time, certainly, military and economic issues have not disappeared nor has their influence diminished, but they increasingly involve social and humanitarian aspects in their orbits. In addition, social and humanitarian actions in the international arena may be perceived as a threat by certain actors. For example, even sponsorship of a foreign sports club could be regarded as interference in internal affairs. All this leads to an increase in the importance of soft security issues. Moreover, the soft security field has significantly expanded.

\section{Humanitarian and Social Issues Reflected in UN Security Council Resolutions}

The question of how the UN Security Council has responded to the growing role of social and humanitarian issues and possible threats to soft security - that it, which aspects are the focus of attention of the Security Council, and their dynamics - guides the empirical research in this article.

Statistical analysis was used to answer this question. The resolutions adopted by the UN Security Council from the beginning of its work in 1946 to 2018 (inclusive) [UN, n. d., a] were analyzed to trace the dynamics of the importance of humanitarian and social issues in the activities of the Security Council. It was assumed that, given the increasing importance of humani- 
tarian and social issues in general, such issues must be at the centre of attention of the Security Council with an upward trend. Resolutions of a social and humanitarian nature are gathered in a single category, "humanitarian resolutions" - the term adopted by the UN. Resolutions relating exclusively to procedural or technical issues, for example the admission of new members to the UN or recommendations regarding the appointment of a new UN secretary-general, were deducted from the total number of resolutions adopted by the Council. Thus, the charts created as a result of the data analysis more clearly demonstrate the correlation of resolutions adopted by the Security Council with a social and humanitarian component to those that deal exclusively with issues of "traditional" security.

Resolutions involving humanitarian and social aspects of peace and security have been divided into three groups. The first group of resolutions - "pure" ones - includes documents devoted exclusively to solutions to humanitarian and social problems arising as a result of a conflict or violation of humanitarian aid requirements, combating human rights violations, humanitarian exclusions from the regime of collective international sanctions, and so on.

The second group - the group of "partial" resolutions - includes documents in which some provisions involve the issues listed above. In this case, only the provisions of the operational parts of the resolutions were taken into account. Documents whose humanitarian and social provisions were of a formal nature were also excluded from the category of "partial" resolutions. In other words, those resolutions that included a humanitarian aspect on a specific issue but did not intend to change the situation or take a specific measure were not considered to be humanitarian or social in nature. Examples of such formal inclusions include clauses in which the Security Council solely "welcomes" a governmental decision of a humanitarian nature or "calls for refraining from violations of international humanitarian law and human rights law" that have not yet occurred.

The third group of humanitarian resolutions includes documents of a normative nature. Such documents were adopted by the Council based not on a consideration of the crisis in any particular country, but on a specific humanitarian issue that concerns all UN member states. In UN practice such agenda items are called "thematic issues." Among the humanitarian and social thematic issues of the Security Council are "Children and Armed Conflict," "HIV/AIDS and International Peacekeeping Operations," "The Role of Civil Society in Post-Conflict Peacebuilding," and others. ${ }^{2}$

Figure 1 demonstrates the general indicators of all Security Council resolutions for the period from 1946 to 2018, and shows the ratio of humanitarian resolutions of all categories to the total number of adopted documents. The number of humanitarian resolutions is growing along with the total number of resolutions. As can be seen, the UN Security Council has begun to pay much more attention to humanitarian issues in recent years.

Figure 2 demonstrates the share of humanitarian resolutions out of all resolutions adopted by the UN Security Council for the years 1946-2018. Since 1991 the share of humanitarian resolutions out of the total number has not dropped below 10\%; since 2007 the number has usually been no less than $20 \%$ and since 2009 it has been no less than 30\%. In 2013, this share reached its maximum at $58.7 \%$ of the total number of UN Security Council resolutions that in one way or another addressed humanitarian issues. Thus, not only is the number of humanitarian resolutions growing along with the general increase in the number of Security Council resolutions, but such resolutions are beginning to occupy an increasingly significant place in the Council's practice.

${ }^{2}$ In Fig. 2 and 3, the "PURE" marker indicates "pure" Council resolutions, the "PART" marker indicates "partial," "NORM" indicates normative, and "PS" indicates resolutions on other issues of international peace and security considered by the Security Council that do not have a humanitarian component. 


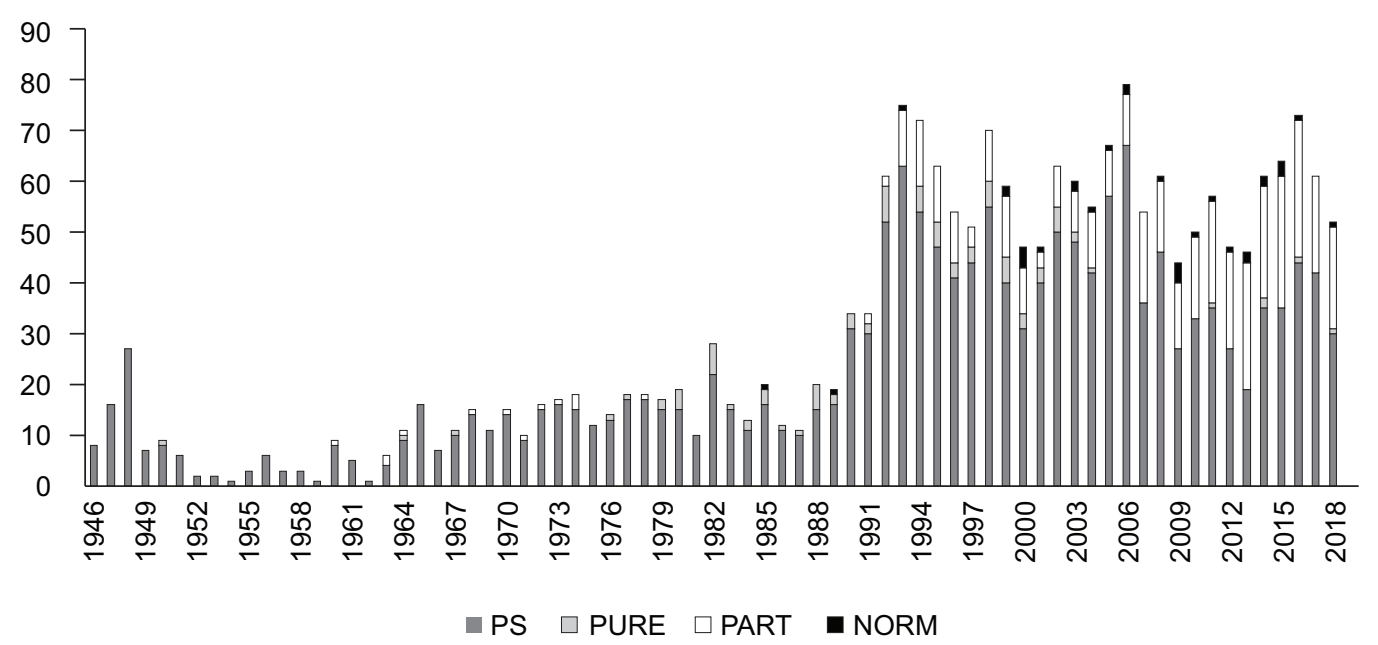

Fig. 1. General Indicators of the Number of All Security Council Resolutions, 1946-2018

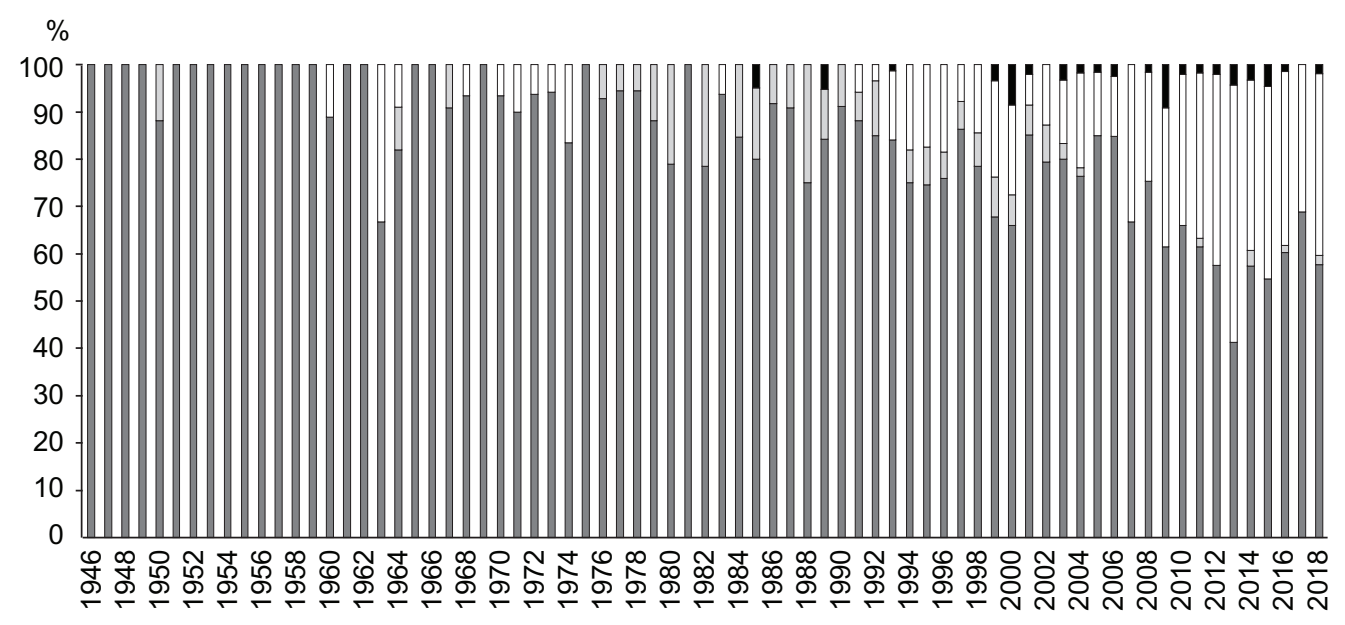

$\square$ PS $\square$ PURE $\square$ PART $\square$ NORM

Fig. 2. The Share of Humanitarian Resolutions Out of All Resolutions Adopted by the UN Security Council, 1946-2018

Figure 3 reflects the dynamics of the number of humanitarian resolutions from 1946 to 2018 in all three categories. The total number of humanitarian resolutions shows cyclical growth. Accordingly, there were some cycles during which the attention of the Security Council to humanitarian issues was either increasing or decreasing. The years in which the number of humanitarian resolutions peaked during the cycle are particularly interesting for study.

In 1950, a resolution was adopted to assist the civilian population of Korea. In the 1960s, the Council began to respond to violations of international humanitarian law; in the 1970s, it began to urge all UN member states to provide humanitarian assistance to states in whose territories armed conflicts take place. In the 1980s, resolutions to alleviate the suffering of civilian populations as a result of conflicts were taken by the Security Council. In the same years, the first normative resolutions appeared. In the 1990s, the Council began to pay more attention to the humanitarian situation in states where armed conflicts were taking place, 


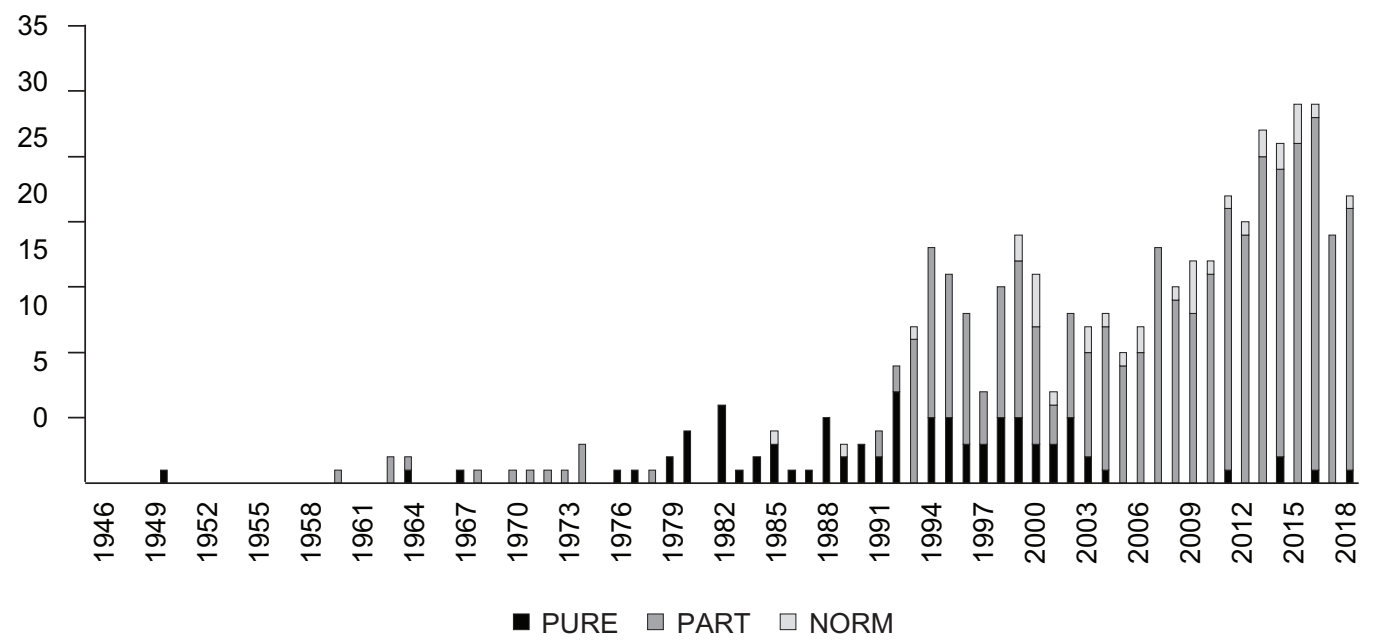

Fig. 3. The Dynamics of the Number of Humanitarian Resolutions of the UN Security Council, 1946-2018

made the first humanitarian exceptions to Security Council measures, raised the issue of the protection of humanitarian personnel, and included the first humanitarian responsibilities in the mandates of its humanitarian assistance and refugee mission. During these years, civilians were divided into categories with special needs - women, children, and refugees. In the 2000s, the Council began to pay attention to such issues as the protection of human rights, the HIV/AIDS epidemic, food security, and the problems of families separated as a result of conflicts. The humanitarian mandates of Security Council missions expanded during this period, and the provisions on the protection of certain categories of civilians were detailed. Extensive attention was given to the gender dimensions of Council missions. In the 2010s, the number of countries in which the situation of the civilian population was of concern to the Security Council increased. The humanitarian provisions of Council resolutions become ever more detailed.

Thus, the "bursts" of humanitarian resolutions up to the 1990s occurred in the years in which international conflicts or emergencies had negative consequences for civilian populations. After the 1990s, the Council focused attention on countries suffering from or recovering from internal conflicts. In addition, the Council began to take measures to protect certain categories of civilians and pay attention to the observance of human rights.

Working documents and transcripts of Security Council meetings show that an increase in interest in humanitarian issues in the Council occurred in 1999-2000, in anticipation of the 2000 Millennium Summit to determine the role of the UN in the new era. In this way, the Security Council tried to adapt to the new, post-bipolar reality. However, neither at the end of the summit, nor in subsequent years, was a document that clearly outlined the terms of reference of the UN Security Council adopted. The wording of Article 39 of the UN Charter [1945] leaves these powers extremely broad - thus, the Council "determines the existence of any threat to peace" and "makes recommendations or decides what measures should be taken" to eliminate such a threat. However, the UN does not observe a "power struggle" between the Security Council and other UN bodies, programmes or specialized agencies. Since the definition of "any threat" includes any soft threats, and the decisions of the Security Council are binding, many states and organizations in the UN system believe that it is the Council that can solve their problems in the most effective way. Representatives of other bodies and agencies in the UN system actively promote their agendas at Council meetings, trying to achieve recogni- 
tion of their problems as "threats to international peace and security" and to secure adoption of mandatory measures to eliminate them. However, this process can significantly complicate the work of the Security Council by distracting the Council from its traditional activities which address the problems of hard security. The increasing pressure on the Security Council is well reflected in Fig. 1. During the reform of the UN Security Council, special attention should be paid not so much to the membership in the body, but to the definition of the terms of reference of the Council and the principles of its relations with other bodies and agencies in the UN system.

\section{The Specifics of Various Social and Humanitarian Issues in the Security Council}

Humanitarian and social issues addressed by the UN Security Council were divided into four groups:

\section{1) Security issues of certain categories of persons in armed conflicts}

Protection of civilians in armed conflict. Although certain aspects of the protection of such persons were enshrined in international conventions, the Security Council paid particular attention to this problem. This is an umbrella issue for the Council, from which all other humanitarian agenda items subsequently stood out. The issue is considered on a regular basis, but not all members of the Council have recognized it as part of the mandate of the body and some have proposed to transfer it to the UN General Assembly (UNGA).

Children and armed conflict. Although the UNGA adopted the Declaration on the Protection of Women and Children in Emergency and Armed Conflict in 1974, the Security Council was able to contribute to the protection of these categories of people in conflict situations. This agenda item was reviewed by the Council on a regular basis, a special working group was created, and detailed resolutions were adopted, including Resolution 1261 which identified six serious violations affecting children during conflict:

- recruitment and use of children;

- killing and mutilating children;

- sexual violence against children;

- attacks on schools and hospitals;

- abduction of children;

- denial of humanitarian access [UN, n. d., b].

The Council emphasized the need to take into account the special needs of girls, urged taking into account the needs of children while providing humanitarian aid, emphasized the negative impact of the illicit arms trade on the life and health of children, and suggested that, where possible, children should be involved in peace processes.

However, although the issue is considered on a regular basis, not all members of the Council have recognized it as part of the mandate of the body and some have suggested transferring it to the General Assembly or the UN Economic and Social Council (ECOSOC) [Ibid., 2009].

Women and peace and security. Namibia and Vietnam (protecting women in conflict situations), as well as the United States (gender equality) sponsored resolutions on this agenda item [Kvinna till Kvinna Foundation, 2010]. By the time this issue was put on the agenda of the Council, many relevant documents had already been adopted. However, the issue was examined on a regular basis, detailed resolutions were adopted, and a special mechanism for monitoring the situation was created. The priority issues for the Council were attracting more women 
to participate in peacekeeping and peacekeeping missions, ensuring the protection of women and girls during conflict, and fair and equal representation of women in decision-making on issues of peace and security. Unfortunately, NGOs indicate that the Council has much more to do in this area [WILPF, n. d.]. In addition, although the issue is reviewed on a regular basis, some members of the Council do not agree with the need for the Council to consider gender equality issues [UN, 2011b].

Protection of UN personnel, associated personnel and humanitarian personnel in conflict zones. At the time of the introduction of this item on the agenda of the Council, the issue was already being actively discussed in the UNGA; the Convention on the Safety of UN Personnel and Associated Personnel was adopted. The Security Council did not take any concrete measures on the issue - its resolutions were in reaction to the attack on the UN headquarters and were intended to draw attention to the problem.

Hostage-taking and kidnapping. This question was first raised by the United States (several U.S. citizens were abducted and killed in 1984-85 in Lebanon) and then by Canada and Finland (which were not states of citizenship of the victims) [Ibid., 1985]. By the time the UN Security Council began to consider this issue, many relevant conventions and documents had already been adopted. Raising this issue, the Security Council exclusively drew attention to the problem: its resolutions were a reaction to the increasing incidence of hostage-taking and kidnapping.

Ensuring the safety of refugees. By the time this item was included in the Council's agen$\mathrm{da}$, this issue was already being dealt with by specialized UN bodies. The Security Council discussed the issue, taking action only for individual countries with a focus on Africa [Ibid., 1998a]. The question of entering the issue into the terms of reference of the Council was not raised and specific discussion of this issue has almost ceased; instead it is reflected in resolutions on the situation in certain countries of the world.

\section{2) Civil aspects of conflict management and peacebuilding}

Consideration of these issues was initiated by the UN secretary-general and the Group of Eminent Persons on the Relationship Between the UN and Civil Society [Ibid., 2004]. The Security Council has become the initial place for consideration of these issues. Not all members of the Council have recognized the issue of the role of civil society in conflict prevention as part of the mandate of the body and some have proposed to transfer it to ECOSOC. As a result, the Security Council formed a specialized body to further work on the issue.

\section{3) Selected soft security issues}

Protection in respect of humanitarian assistance to refugees and others during conflicts. This issue has long been dealt with by other UN agencies and other organizations, and the Security Council joined the discussions only after an appeal by the UN secretary-general. The Council limited itself to debates on this issue, and subsequently included paragraphs relating to humanitarian assistance only in separate resolutions on the situation in specific countries of the world.

HIV/AIDS and international peacekeeping operations. The Security Council was the first to address HIV/AIDS in the context of conflict. The Security Council drew attention to the issue, pointing out the problems of access to HIV/AIDS care and treatment, the need to train peacekeeping personnel and other employees of international organizations in the field of disease prevention [Ibid., 2000a; 2011a]. The inclusion of the issue in the agenda of the Council was disputed by some members of the body. This issue has almost ceased to be discussed, and it has been put into the preambles of resolutions on the situation in certain countries of the world. 
Climate change in the context of international security. Consideration of this issue was initiated at different times by Great Britain, a permanent member of the Council, and also by Germany and the small island states as non-permanent members. Consideration of this agenda was limited to discussions, since the issue was not recognized as falling within the mandate of the Council.

Food and security. The World Food Programme initiated the inclusion of this issue on the agenda of the Council. The Security Council was one of the first to consider the problem of food shortages in the context of ensuring international security. However, consideration of this problem was limited to discussions, and it was adopted in a resolution on the situation in certain countries of the world.

\section{4) Problems of human rights protection}

Various forces have initiated the consideration of these issues by the Security Council, and the agenda was pushed more often for political reasons than for humanitarian ones. The Security Council is holding back consideration of this group of issues, and human rights violations are either referred to specialized bodies (the UN Human Rights Council), considered at informal meetings, or detailed questions are rejected.

\section{Motives to Put Humanitarian Resolutions on the Security Council's Agenda}

On the whole, the UN Security Council did not have a specific mechanism for including humanitarian issues on its agenda - each issue was included for its own reasons and took place at different stages of the development of such issues at the international level. The process of including humanitarian issues on the Council's agenda has not been homogeneous primarily because the initiative to include such issues came from various states or groups of states, and other actors with various motives.

The following groups of lobbyists pushed the humanitarian agenda in the UN Security Council at different times:

\section{1) Non-permanent members of the Security Council that wanted to leave their mark on the history of the Council}

Since non-permanent members usually seek to leave a positive legacy from their period of Security Council membership, they are often the ones that initiate the inclusion of relevant issues on the agenda [German Institute for Human Rights, 2012, p. 1]. One example is Germany (2011-12), which sought to ensure that the Council considered the security-related effects of climate change [Ibid., p. 4]. However, the most illustrative example in this regard is Canada (1999-2000). Canada wanted to restore trust in UN peacekeeping that had been lost after the tragic events in Rwanda, Bosnia and Somalia. Canada promoted a more interventionist approach to maintaining international peace and security, and for this purpose advanced the issue of "human security"' in the Council. As its foreign minister, Lloyd Axworthy, said before Canada took a seat on the Council: "Canada will work to form a more proactive, problem-oriented Council that will focus on the human dimension of security" [Donais, 1999, p. 18].

${ }^{3}$ Defined by the UNDP [1994] as "freedom from fear" and "freedom from want" in economic, food, health, environmental, personal, community and political dimensions. 
However, in practice, Canada encountered a number of challenges. Canada needed to convince the five permanent members of the Council to take the concept of human security seriously. Canada should have taken into account the cautious attitude of Russia and China toward interference in the internal affairs of other states. It also had to convince the United States of the appropriateness of spending resources to achieve the goals of human security, which did not always correspond to American national interests [Donais, 1999, p. 19].

In addition, the very composition of the Security Council in 1999-2000 could complicate the promotion of the principles of human security. At that time, the developing world in the Security Council was represented by such micro-powers as Bahrain and The Gambia, and the Human Development Report: New Dimensions of Human Security Council might not have sufficient legitimacy for a cardinal transition to the human security approach [UN, n. d., a].

However, there was an increase in the Council's interest in the human security agenda in 1999-2000. Canada succeeded in creating a Human Security Network partnership to advance human security concerns, including Norway, Austria, Ireland, Switzerland, Thailand, the Netherlands, Slovenia, Jordan, Chile and South Africa [Dedring, 2004, pp. 67-8]. ${ }^{4}$ Later, Japan and Korea also expressed support for the ideas of the group [Ibid., p. 73]. The latter, during its presidency of the Security Council, acted as the initiator of open meetings on some humanitarian issues.

\section{2) Politicians for whom the humanitarian agenda was at a premium}

In some cases, the introduction of a humanitarian issue on the agenda of the Security Council was made by one person. In this regard, the UN secretary-general in 1997-2006, Kofi Annan, can be especially noted. Annan actively promoted issues on the Security Council which he considered his "personal priorities," such as the fight against HIV/AIDS [UN, 2006] and humanitarian initiatives in Africa [Ibid., 1998b].

Another striking example was the minister of foreign affairs of the Republic of Namibia, Theo-Ben Gurirab, who promoted the protection of children in armed conflicts during his presidency of the Security Council and the UN General Assembly in 1999-2000.

\section{3) Particular bodies and organizations in the UN system, mainly with humanitarian mandates}

The introduction of humanitarian issues on the agenda of the Security Council has been sought by many bodies, organizations and agencies in the UN system, as they want to draw the attention of the public and sponsors to their activities and reinforce them with the authority of the Council. For example, at the Security Council meeting on HIV/AIDS and international peacekeeping operations, the executive director of the Joint United Nations Programme on HIV/AIDS (UNAIDS) explicitly noted that a consideration of HIV/AIDS as not only a health issue but also as an issue of security and development will fundamentally change the approach to the resources that can be used to solve this problem, which will greatly assist UNAIDS in carrying out its activities [Ibid., 2011, p. 815].

New opportunities to advance their agenda opened up for UN agencies in 1992, when "Arria formula" meetings became part of the practice of the UN Security Council. Such meetings may include invitations of UN organizations and agencies with humanitarian mandates, heads of international organizations, persons holding high posts at the UN, or representatives of NGOs and civil society [Security Council Report, 2019]. Such meetings were conceived as informal,

\footnotetext{
${ }^{4}$ According to other sources, also Greece and Mali [UN, 2011b, p. 804].
} 
confidential meetings for the frank exchange of private opinions on issues covered by the powers of the Security Council [Permanent Mission of Russia to the UN, 2016]. However, the format began to be used in cases where the Security Council could not reach an agreement on holding an official meeting because of the controversy of the issue under discussion. Examples of such Arria formula meetings include the briefing by the UN secretary-general on security aspects related to climate change (15 February 2013), as well as the meeting on human rights in Syria, which was scheduled immediately after the failed procedural vote on inclusion of this issue on the official agenda of the Council (19 March 2018) [Security Council Report, 2019]. Human rights violations in various parts of the world were often discussed at Arria formula meetings. The inclusion of such issues on the official agenda has been promoted by the UN High Commissioner for Human Rights [OHCHR, 2017] and representatives of human rights organizations.

\section{4) Non-governmental organizations}

NGOs also actively participate in Arria formula meetings. For example, Human Rights Watch and Freedom House took part in the meeting on the human rights situation in Crimea (18 March 2016) [UN News, 2016]. In general, NGOs have roughly the same goals as the humanitarian units in the UN system. However, if the latter are interested in the issues they advance within the $\mathrm{UN}$, for NGOs it is important to cover their activities in the media. Although meetings according to the Arria formula were conceived as confidential, they are periodically broadcasted. The Russian Federation, for example, claims that such meetings are sometimes used as a means of advertising to the media and NGOs, which undermines the prestige of the Security Council [Interfax, 2014].

NGOs also seek to use the authority of the Council to assist in their activities. For example, the International Committee of the Red Cross supported the adoption of Security Council resolutions on the protection of humanitarian personnel in conflict zones [ICRC, 2018].

Some NGOs not participating in Security Council meetings seek to influence its activities from outside. For example, the oldest women's organization, the International Women's League for Peace and Freedom, has created a special project called "PeaceWomen" to monitor the UN system and to improve the status of women in conflict and post-conflict periods [WILPF, n. d.].

When lobbying humanitarian issues in the Security Council, the above-mentioned groups often encounter resistance coming from the following groups:

\section{1) Some developing countries}

The promotion of humanitarian issues in the UN Security Council is often hindered by some developing countries that consider humanitarian issues to be within the internal competence of states and fear encroachment on their own sovereignty. Tunisia, Brazil, Angola, Venezuela and others are among such countries. They usually vote against holding meetings to discuss human rights and are wary of humanitarian interventions and unhindered humanitarian access.

\section{2) The members of the Permanent Five in case of conflict between humanitarian issues and their interests}

There are opinions that the behaviour of the permanent members of the Security Council is the main reason for the inconsistency of the Council's practice in combating human rights violations [German Institute for Human Rights, 2012, p. 3]. Thus, meetings on the human rights situation in Palestine, the Democratic People's Republic of Korea and Crimea were blocked. 


\section{3) Security Council members opposing a broad interpretation of the concept of security and the expansion of the Council's powers}

Such members of the Security Council believe that an expanded interpretation of the concept of security and an expansion of the mandate of the Council will impede its activities and will contribute to the "crawling" of the powers of other UN bodies and agencies to the Council.

Vivid examples of countries making such statements are India and China. They either call for referring the matter to other bodies such as the UNGA, ECOSOC or the Human Rights Council, as was the case with the agenda item "Children and Armed Conflicts" [UN, 2009] or they state that a problem is contrived, as in the case of HIV/AIDS.

\section{The Main Results of the Study}

Since the end of the 20th century, the importance of humanitarian and social issues has sharply increased. Issues of a humanitarian and social nature began to be actively included in the agenda of the UN Security Council, traditionally focused on protecting states from hard threats to security. The catalyst for the inclusion of humanitarian items on the agenda of this body was the Millennium Summit of 2000, the goal of which was to determine the role of the UN in the new era. The Security Council tried to adapt to a new reality. The growing importance of humanitarian issues for the Security Council is well demonstrated by the correlation of resolutions affecting the issues of hard and soft security.

Thus, in the late 1990s and early 2000s, the UN Security Council began to consider a rather large amount of humanitarian issues, which can be divided into three groups. The first includes issues of the security of individuals in armed conflicts (civilians, children, women, UN and humanitarian personnel). The second includes civilian aspects of conflict management and peacebuilding, including the role of civil society and individual actors in conflict prevention and post-conflict peacebuilding. The third includes various issues of soft security (including issues of humanitarian assistance and such soft threats to security as HIV/AIDS epidemics, food crises and climate change). In addition, the Council also addressed human rights violations in its resolutions.

Thus, in the 1990s and 2000s, the range of humanitarian issues discussed by the Security Council expanded, as did the list of actors who introduced Security Council resolutions on humanitarian issues. The promotion of humanitarian issues in the Council at different times was facilitated by: high-ranking officials who put a premium on humanitarian issues; various bodies and organizations in the UN system, mainly with humanitarian mandates; some nonpermanent members of the Security Council that wanted to leave their mark on the history of the Council; and, various NGOs. In turn, some countries opposed the adoption by the Security Council of measures on issues they considered to be within the internal competence of states.

The Security Council adopted resolutions on issues of soft security, widely interpreting its right to determine the existence of "any threat to peace" in accordance with Article 39 of the UN Charter. At the same time, the increase and expansion of humanitarian and social issues in the world posed a dilemma for the UN Security Council as to whether to include the full range of these issues on the agenda or to decide that they are beyond the mandate of the Council. There is no definite answer here. On the one hand, the trend is toward a strengthening of the humanitarian agenda and its ever-greater involvement in security issues, while on the other hand, an expanded interpretation of the concept of security may impede the work of the Council. This dilemma should be resolved by UN member states through a reform of the Security Council to define a closed list of the powers of the body. 


\section{References}

Bombardir.ru (2018). "Gazprom” sponsiruyet evropeyskiy futbol: zachem, kak i skolko [Gazprom Sponsors European Football: Why, How and How Much]. Available at: https://bombardir.ru/articles/455270-Gazpromsponsiruet-evropeyskiy-futbol-zachem-kak-i-skolko (accessed 24 August 2019). (in Russian)

British Petroleum (BP) (2005). Novyye podkhody i resheniya: otchet ob ustoychivom razvitii za 2005 god [New Approaches and Solutions. Sustainable Development Report for 2005]. Available at: http://xn--olaabe.xn-p1ai/12/3912.pdf (accessed 24 August 2019). (in Russian)

Buzan B. (1983) People, States, and Fear: The National Security Problem in International Relations. Brighton: Wheatsheaf Books.

Buzan B., Waever O., De Wilde J. (1998) Security: A New Framework for Analysis. Boulder: Lynne Rienner Publishers.

Davies S.E. et al. (2014) Global Health in International Relations: Editors' Introduction. Review of International Studies, vol. 40, pp. 825-834.

Dedring J. (2004) Human Security and the UN Security Council. IPSHU English Research Report Series "Conflict and Human Security: A Search for New Approaches of Peace-building", no 19.

Donais T. (1999) Of Soft Power and Human Security: Canada and the U.N. Security Council. Peace Magazine.

Galtung J. (1969) Violence, Peace, and Peace Research. Journal of Peace Research, vol. 6, no 3, pp. 167-191.

German Institute for Human Rights (2012). The Role of the UN Security Council in Protecting Human Rights: Prospects and Challenges. The Materials of an Expert Workshop. Available at: https://webcache. googleusercontent.com/search?q=cache:S45YnGNPbBkJ:https://www.institut-fuer-menschenrechte.de/ fileadmin/user_upload/Word/Bericht_The_Role_of_the_UN_Security_Council_in_Protecting_HR_2012. $\mathrm{doc}+\& \mathrm{~cd}=1 \& \mathrm{hl}=\mathrm{ru} \& \mathrm{ct}=\mathrm{clnk} \& \mathrm{gl}=\mathrm{ru}($ accessed 24 August 2019$)$.

Human Development Report (1994). United Nations Development Programme. New York, Oxford University Press.

Interfax (2014). Rossiya otkazalas ot uchastiya v neformalnom zasedanii SB OON po Krymu [Russia Refused to Participate in an Informal Meeting of the UN Security Council on Crimea]. Available at: https://www.interfax.ru/world/368590 (accessed 24 August 2019). (in Russian)

International Committee of the Red Cross (ICRC) (2018). ICRC: Medical Workers are Attacked Every Week. Available at: https://www.icrc.org/en/document/icrc-health-care-workers-suffer-attacks-every-single-week (accessed 24 August 2019).

Komsomolskaya Pravda (2018) "Belyye kaski" ishchut v Sirii dobrovoltsev, chtoby otravit ikh khlorom ["White Helmets" Are Looking for Volunteers in Syria to Poison Them With Chlorine]. Available at: https://www. kp.ru/daily/26902.4/3946959/ (accessed 24 August 2019). (in Russian)

Kvinna till Kvinna Foundation (2010). Review of the Security Council Resolutions on Women, Peace and Security. Equal Power-Lasting Peace Initiative. Available at: http://www.equalpowerlastingpeace.org/ru/resource/obzor-vseh-rezolyutsiy-sb-oon-o-zhenshhinah-mire-i-bezopasnosti/ (accessed 24 August 2019). (in Russian)

Lebedeva M.M. (2006) Politikoobrazuyushchaya funktsiya vysshego obrazovaniya v sovremennom mire [The Politico-Forming Function of Higher Education in the Modern World]. Mirovaya ekonomika i mezhdunarodnyye otnosheniya [World Economy and International Relations], no 10, pp. 69-75. (in Russian)

Lebedeva M.M. (2014) Resursy vliyaniya v mirovoy politike [Resources of Influence in World Politics]. Polis, no 1, pp. 99-108. (in Russian)

Nye J. (1990) Bound to Lead: The Changing Nature of American Power. New York: Basic Books.

Office of the United Nations High Commissioner for Human Rights (OHCHR) (2017). Arria Formula Meeting on the Situation in Venezuela. Statement by the United Nations High Commissioner for Human Rights, Mr. Zeid Raad Al Hussein. Available at: https://www.ohchr.org/EN/NewsEvents/Pages/DisplayNews. aspx?NewsID=22392\&LangID=E (accessed 24 August 2019). 
Postoyannoye predstavitelstvo Rossiyskoy Federatsii pri Organizatsii Obyedinennykh Natsiy [Permanent Mission of the Russian Federation to the United Nations] (2016). Vystupleniye Pervogo zamestitelya Postoyannogo predstavitelya Rossiyskoy Federatsii pri OON P.V. Ilicheva na zasedanii po itogam raboty Soveta Bezopasnosti OON v avguste 2016 goda [Speech by the First Deputy Permanent Representative of the Russian Federation to the UN, P.V. Ilyichev, at the Meeting on the Results of the Work of the UN Security Council in August 2016]. Available at: http://russiaun.ru/ru/news/sc_wusag (accessed 24 August 2019). (in Russian)

Rudenkova D.E. (2015) Lobbizm v institutakh Evropeyskogo soyuza [Lobbying in the Institutions of the European Union]. Mezhdunarodnyye protsessy [International Processes], no 13, pp. 68-80. (in Russian)

Security Council Report (2019). UN Security Council Working Methods: Arria-Formula Meetings. Available at: https://www.securitycouncilreport.org/un-security-council-working-methods/arria-formula-meetings. php (accessed 24 August 2019).

Stepanova E.A. (2007) Gumanitarnyy potentsial Rossii i vosstanovleniye ekonomiki konfliktnykh zon [The Humanitarian Potential of Russia and the Restoration of the Economy of Conflict Zones]. Mirovaya ekonomika i mezhdunarodnyye otnosheniya [World Economy and International Relations], no 5, pp. 65-78. (in Russian)

Strange S. (1989) Toward a Theory of Transnational Empire. Global Changes and Theoretical Challenges: Approaches to World Politics for the 1990's / E.-O. Czempiel, J.N. Rosenau (eds). Lexington Books.

Tsygankov P.A. (2015) "Gibridnyye voyny": ponyatiye, interpretatsii i realnost [Hybrid Wars: Concept, Interpretation, and Reality]. "Gibridnyye voyny" v khaotiziruyushchemsya mire XXI veka [Hybrid Wars in the Chaotic World of the XII Century] (P.A. Tsygankova (ed.)). Moscow: MSU, pp. 7-32. (in Russian)

UN News (2016). The UN Hosted a Meeting of the UN Security Council "According to the Arria Formula," Dedicated to the Human Rights Situation in Crimea. Available at: https://news.un.org/ru/story/2016/03/1282151 (accessed 24 August 2019). (in Russian)

United Nations (UN) (1945). United Nations Charter. Available at: https://www.un.org/ru/charter-unitednations/ (accessed 5 November 2019).

United Nations (UN) (1946-2019). UN Security Council Member Search. Available at: https://www.un.org/ securitycouncil/search/member (accessed 24 August 2019).

United Nations (UN) (1985). Letter Dated 16 December 1985 from the Permanent Representative of the United States to the United Nations Addressed to the President of the Security Council S/17685. Available at: https://undocs.org/en/S/17685 (accessed 24 August 2019).

United Nations (UN) (1998a). Security Council Resolution 1208 (1998) on the Situation in Africa: Refugee Camps. Available at: https://undocs.org/en/S/RES/1208(1998) (accessed 24 August 2019).

United Nations (UN) (1998b). The Causes of Conflict and the Promotion of Durable Peace and Sustainable Development in Africa: Report of the Secretary-General. Fifty-Second Session of the General Assembly. Available at: https://undocs.org/en/A/52/871 (accessed 24 August 2019).

United Nations (UN) (2000a). HIV/AIDS and Peacekeeping Operations. Security Council Resolution 1308 (2000). Available at: https://undocs.org/en/S/RES/1308(2000) (accessed 24 August 2019).

United Nations (UN) (2000b). Global Compact. Available at: https://www.unglobalcompact.org/ (accessed 24 August 2019).

United Nations (UN) (2004). We, the Peoples: Civil Society, the United Nations and Global Governance. Report of the Panel of Eminent Persons on the Relationship Between the United Nations and Civil Society. General Assembly Document A/58/817. Available at: https://undocs.org/en/A/58/817 (accessed 24 August 2019).

United Nations (UN) (2006). Former Secretary-General Kofi Annan. Available at: https://www.un.org/sg/en/ content/kofi-annan (accessed 24 August 2019).

United Nations (UN) (2011). Maintaining International Peace and Security. Security Council Resolution 1983 (2011). Available at: https://undocs.org/en/S/RES/1983(2011) (accessed 24 August 2019).

United Nations (UN) (n. d., a). UN Security Council Resolutions. Available at: https://www.un.org/securitycouncil/content/resolutions-0 (accessed 24 August 2019).

United Nations (UN) (n. d., b). The Special Representative of the Secretary-General for Children and Armed Conflict. Available at: https://childrenandarmedconflict.un.org/about-us/ (accessed 24 August 2019). 
United Nations (UN) (1996-1999). Children and Armed Conflicts: Initial Review. Security Council Electronic Handbook 1996-1999. Available at: https://www.un.org/en/sc/repertoire/96-99/Chapter\%208/Thematic/96_99_8_Thematic_39_Children\%20and\%20armed\%20conflict.pdf (accessed 24 August 2019).

United Nations (UN) (2000-2003). Security Council Electronic Handbook 2000-2003. Available at: https:// www.un.org/en/sc/repertoire/2000-2003/Chapter\%208/Thematic/00-03_8_43\%20Women\%20and\%20 peace\%20and\%20security\%201.pdf (accessed 24 August 2019).

Women's International League for Peace and Freedom (WILPF) (2000-2019). Peace Women project: Security Council Monitoring. Available at: http://peacewomen.org/security-council (accessed 24 August 2019). 